\title{
Norepinephrine Promotes Microglia to Uptake and Degrade Amyloid $\beta$ Peptide through Upregulation of Mouse Formyl Peptide Receptor 2 and Induction of Insulin-Degrading Enzyme
}

\author{
Yan Kong, Lingfei Ruan, Lihua Qian, Xiaolei Liu, and Yingying Le \\ Key Laboratory of Nutrition and Metabolism, Institute for Nutritional Sciences, Shanghai Institutes for Biological Sciences, Chinese Academy of Sciences, \\ Graduate School of the Chinese Academy of Sciences, Shanghai 200031, People’s Republic of China
}

Locus ceruleus (LC) is the main subcortical site of norepinephrine synthesis. In Alzheimer's disease (AD) patients and rodent models, degeneration of LC neurons and reduced levels of norepinephrine in LC projection areas are significantly correlated with the increase in amyloid plaques, neurofibrillary tangles, and severity of dementia. Activated microglia play a pivotal role in the progression of AD by either clearing amyloid $\beta$ peptide $(\mathrm{A} \beta)$ deposits through uptake of $\mathrm{A} \beta$ or releasing cytotoxic substances and proinflammatory cytokines. Here, we investigated the effect of norepinephrine on $\mathrm{A} \beta$ uptake and clearance by murine microglia and explored the underlying mechanisms. We found that murine microglia cell line N9 and primary microglia expressed $\beta_{2}$ adrenergic receptor (AR) but not $\beta_{1}$ and $\beta_{3} \mathrm{AR}$. Norepinephrine and isoproterenol upregulated the expression of $\mathrm{A} \beta$ receptor $\mathrm{mFPR} 2$, a mouse homolog of human formyl peptide receptor FPR2, through activation of $\beta_{2} A R$ in microglia. Norepinephrine also induced mFPR2 expression in mouse brain. Activation of $\beta_{2} \mathrm{AR}$ in microglia promoted $\mathrm{A} \beta_{42}$ uptake through upregulation of mFPR 2 and enhanced spontaneous cell migration but had no effect on cell migration in response to mFPR 2 agonists. Furthermore, activation of $\beta_{2} \mathrm{AR}$ on microglia induced the expression of insulin-degrading enzyme and increased the degradation of $\mathrm{A} \beta_{42}$. Mechanistic studies showed that isoproterenol induced mFPR2 expression through ERK1/2-NF- $\kappa$ B and p38-NF- $\kappa$ B signaling pathways. These findings suggest that noradrenergic innervation from LC is needed to maintain adequate $\mathrm{A} \beta$ uptake and clearance by microglia, and norepinephrine is a link between neuron and microglia to orchestrate the host response to $\mathrm{A} \beta$ in $\mathrm{AD}$.

\section{Introduction}

Alzheimer's disease $(\mathrm{AD})$ is a chronic neurodegenerative disease. It is the most frequent cause of dementia in the elderly. AD brain pathology is characterized by amyloid plaques, neurofibrillary tangles, and neuronal loss (Hardy and Higgins, 1992; Selkoe, 1999; Mudher and Lovestone, 2002). Activated microglia and astrocytes were usually found to be associated with the amyloid plaques. Activation of microglia leads to uptake and clearance of amyloid $\beta$ peptide (A $\beta$ ) (Frautschy et al., 1998; Qiu et al., 1998; Simard et al., 2006; Hickman et al., 2008). However, excessive activation of microglia leads to production and release of inflammatory cytokines, nitric oxide, and reactive oxygen species,

\footnotetext{
Received June 10, 2010; revised July 14, 2010; accepted July 18, 2010.

This work was supported by grants from National Basic Research Program of China (2010CB529701), National Natural Science Foundation of China (30570557, 30970917), One Hundred Talents Program of Chinese Academy of Sciences and the Chief Scientist Program of Shanghai Institutes for Biological Sciences (SIBS2008006), Chinese Academy of Sciences, and the Science and Technology Commission of Shanghai Municipality (04ZR14151, 07DJ14005, 09ZR1436700). We thank Drs. P. Ricciardi-Castagnoli (Universita Degli Studi di Milano-Bicocca, Milan, Italy) and Ji Ming Wang (National Cancer Institute, Frederick, MD) for the generous gift of N9 cells and mFPR2/293 cells, respectively, and Dr. David Baltimore (California Institute of Technology, Pasadena, CA) for kindly providing plasmids pBS-hU6-I, FG12, pRSV/REV, pMDLG/pRRE, and pHCMVG/VSVG.

Correspondence should be addressed to Yingying Le at the above address. E-mail: yyle@sibs.ac.cn.

DOI:10.1523/JNEUROSCI.2985-10.2010

Copyright $\odot 2010$ the authors $\quad 0270-6474 / 10 / 3011848-10 \$ 15.00 / 0$
}

which contribute to neuronal dysfunction and cell death (Griffin et al., 1998).

The locus ceruleus (LC) is a noradrenergic nucleus located in the pontine tegmentum and serves as the main subcortical site for the synthesis of norepinephrine (NE) and its precursor enzymes (Freedman et al., 1975). Ascending noradrenergic axons project to the hippocampus, the frontal and entorhinal cortices, and to a minor extent to various other brain regions. Degeneration of LC neurons and reduced levels of NE in LC projection areas are well known features of $\mathrm{AD}$. In $\mathrm{AD}$ patients the central portion of the LC, which is considered to project predominantly to the hippocampus, frontal and temporal cortex areas that are usually severely affected by senile plaque and neurofibrillary tangle formation, shows the most extensive loss of cells (Marcyniuk et al., 1986). The decreased LC neuron numbers are significantly correlated with the increase of amyloid plaques, neurofibrillary tangles, and severity of dementia (Marcyniuk et al, 1986; Bondareff et al., 1987; Grudzien et al., 2007; Weinshenker, 2008). In rodent $\mathrm{AD}$ models, neurotoxin $\mathrm{N}$-(2-chloroethyl)- $\mathrm{N}$-ethyl-bromobenzylamine (DSP4)-induced LC neuron degeneration and NE deficiency exacerbate $\mathrm{A} \beta$ deposition, inflammation, neurodegeneration in brain, and cognitive impairment (Heneka et al., 2006; Kalinin et al., 2007). NE supplement can ameliorate the inflamma- 
A

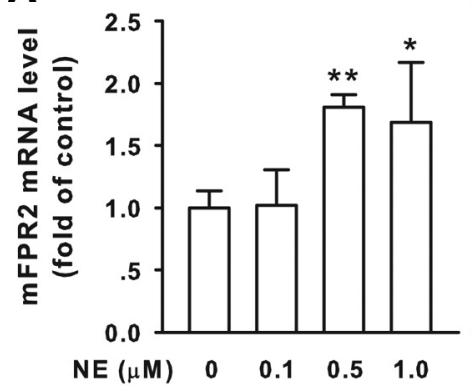

C

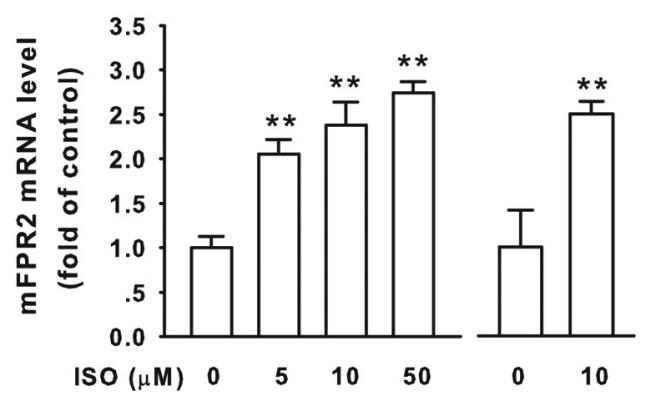

Figure 1. Norepinephrine and isoproterenol induce mFPR2 gene expression in microglia and brain. N9 cells $(\boldsymbol{A}, \boldsymbol{C})$ or murine primary microglia $(\boldsymbol{B}, \boldsymbol{D})$ were incubated with different concentrations of NE $(\boldsymbol{A}, \boldsymbol{B})$ for $6 \mathrm{~h}$ or ISO $(\boldsymbol{C}, \boldsymbol{D})$ for $9 \mathrm{~h}$, and then total RNA was extracted and examined for $m F P R 2 m R N A$ level by real-time $P C R$. Results represent the mean $\pm S D$ of three independent experiments. ${ }^{*} p<0.05,{ }^{* *} p<0.01$ versus cells cultured with control medium.

A

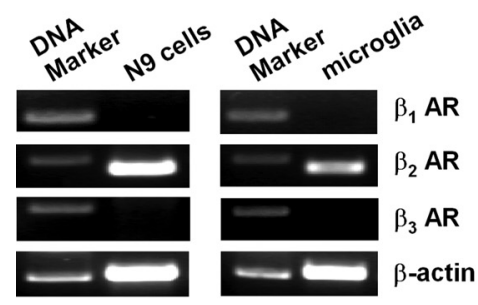

B

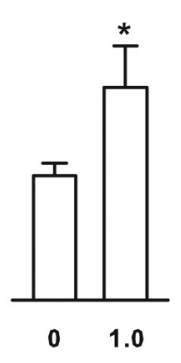

D

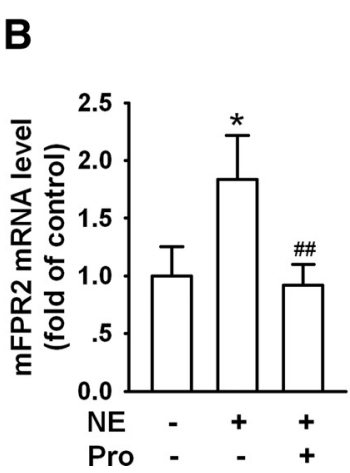

tactic activity of $\mathrm{A} \beta_{42}$ (Le et al., 2001; Yazawa et al., 2001; Iribarren et al., 2005; Chen et al., 2006). In this study, we report that activation of the $\beta_{2}$ adrenergic receptor (AR) on microglial cells induces the expression of mFPR2 through ERK1/2-NF $\kappa$ B and p $38 \mathrm{NF}-\kappa \mathrm{B}$-dependent signaling pathways (where ERK1/2 is extracellular signal-regulated kinase $1 / 2$ and NF- $\kappa \mathrm{B}$ is nuclear factor $\kappa \mathrm{B})$. Microglial cells activated by $\beta \mathrm{AR}$ agonist exhibited a markedly increased capacity to endocytose $\mathrm{A} \beta_{42}$ through mFPR2 and to degrade $\mathrm{A} \beta_{42}$ through upregulation of the $\mathrm{A} \beta$-degrading enzyme, insulin-degrading enzyme (IDE).

\section{Materials and Methods}

Reagents. $\mathrm{A} \beta_{42}$ was purchased from California Peptide Research. $\mathrm{A} \beta_{42}$ was dissolved in DMSO at a concentration of $2 \mathrm{~mm}$ as stock solution and kept at $-70^{\circ} \mathrm{C}$. Norepinephrine, isoproterenol (ISO), and propranolol were purchased from Sigma. W peptide (WKYMVm) and MMK-1 (LESIFRSLLFRVM) were synthesized and purified by the Department of Biochemistry, Colorado State University (Fort Collins, CO). SB203580, PD098059, SP600125, and BAY117082 were obtained from Calbiochem. Antibodies against total or phosphorylated ERK1/2, p38, c-jun $\mathrm{N}$-terminal kinase (JNK), and I $\kappa \mathrm{B} \alpha$ were purchased from Cell Signaling Technology. Mouse anti-A $\beta$ antibody and anti-actin monoclonal antibody were from Sigma. The $6 \mathrm{E} 10$ antibody against $\mathrm{A} \beta$ was from $\mathrm{Co}-$ vance. Antibodies against neprilysin and insulin-degrading enzyme were from Millipore. HRP-conjugated secondary antibodies were from Proteintech. DMEM and Iscove's modified Dulbecco's medium (IMDM) were purchased from Invitrogen. Fetal bovine serum (FBS) was from Hyclone.

Cell culture. Primary mouse microglia was isolated and purified from whole brain of newborn C57BL/6 mice as described previously (Xu and Drew, 2006). The experiments using animals were in accordance with the National Institutes of Heath Guide for the Care

Figure 2. Norepinephrine and isoproterenol upregulate mFPR2 expression through activation of $\beta_{2} A R$. $A$, The expression of $\beta$ adrenergic receptors in $\mathrm{N} 9$ cells and mouse primary microglia was examined by RT-PCR. $B, C$, N9 cells pretreated with $10 \mu \mathrm{m}$ propranolol (Pro) for $1 \mathrm{~h}$ were incubated with or without $1 \mu \mathrm{m} \mathrm{NE}$ for $6 \mathrm{~h}(\boldsymbol{B})$ or $10 \mu \mathrm{m} I S 0$ for $9 \mathrm{~h}(\boldsymbol{C})$, and total RNA was extracted and examined for $m F P R 2 m R N A$ level by real-time $P C R$. Results represent the mean $\pm S D$ of three independent experiments. ${ }^{*} p<$ 0.05 versus cells cultured with control medium. ${ }^{\#} p<0.05,{ }^{\# \#} p<0.01$, compared with cells treated with NE or ISO alone.

tion induced by $\mathrm{LC}$ degeneration in mouse $\mathrm{AD}$ models (Heneka et al., 2002). These results suggest that NE has protective effect against $\mathrm{AD}$ lesions. In vitro studies showed that NE could promote $\mathrm{A} \beta$ uptake by murine microglia (Kalinin et al., 2007; Heneka et al., 2010). However, the underlying mechanisms and the effect of NE on $\mathrm{A} \beta$ clearance and the expression of enzymes involved in $\mathrm{A} \beta$ degradation by microglia are not clear.

Our previous studies revealed that human $\mathrm{G}$ protein-coupled receptor formyl peptide receptor 2 (FPR2) and its mouse homolog mFPR2 are functional receptors for $\mathrm{A} \beta$ (Le et al., 2001; Tiffany et al., 2001; Yazawa et al., 2001). FPR2 is expressed at high levels by mononuclear (microglial) cells infiltrating senile plaques in brain tissues from $\mathrm{AD}$ patients (Le et al., 2001). FPR2/ mFPR2 mediates the uptake of $\mathrm{A} \beta$ by microglia and the chemo-

\section{C}

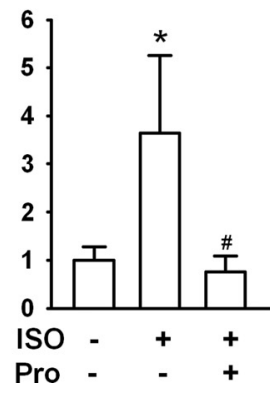
and Use of Laboratory Animals and were approved by the Biological Research Ethics Committee, Institute for Nutritional Sciences, Chinese Academy of Sciences (Shanghai, China). Murine microglial cell line N9 was grown in IMDM supplemented with 5\% heatinactivated FBS, $2 \mathrm{~mm}$ glutamine, $100 \mathrm{U} / \mathrm{ml}$ penicillin, $100 \mu \mathrm{g} / \mathrm{ml}$ streptomycin, and $10 \mu \mathrm{M}$ 2-mercaptoehtanol (2-ME). mFPR2/293 cells expressing myc-tagged mFPR2 (Ying et al., 2004) were maintained in DMEM containing $10 \%$ FCS, $800 \mu \mathrm{g} / \mathrm{ml} \mathrm{G} 418,100 \mathrm{U} / \mathrm{ml}$ penicillin, and $100 \mu \mathrm{g} / \mathrm{ml}$ streptomycin.

Reverse transcription $P C R$ and quantitative real-time PCR. Total RNA was extracted from cells with TRIzol reagent (Invitrogen) and depleted of contaminating DNA with RNase-free DNase. Reverse transcription (RT) of RNA was performed with Moloney murine leukemia virus reverse transcriptase (Fermentas) and oligo(dT) according to the manufacturer's protocol. The primers of PCR were: $\beta_{1} \mathrm{AR}$ (sense: $5^{\prime}$-TCGCTACCAGAGTTTGCTGACGC, antisense: $5^{\prime}$-AACACCCGCAGGTACACGAAGG); $\beta_{2}$ AR (sense: $5^{\prime}$-CGACTACAAACCGTCACCAA-3', antisense:5' -ATAGCGATCCACTGCAATCA-3'); $\beta_{3}$ AR (sense: 5'-ATGACTAGACCACGAGGTGTAAGG-3', antisense: 5' -CAGGGTTAGGAAAGCAGTAGGA-3'); mFPR1 (sense: 5' -CAGCCTGTACTTTCGACTTCTCC- ${ }^{\prime}$, antisense: $5^{\prime}$-ATTGGTGCCTGTATCACTGGTCT- ${ }^{\prime}$ ); mFPR2 (sense: 5'-CTTTATCTGCTGGTTTCCCTTTC-3', antisense: 5'-CTGGTGCTTGAATCACTGGTTTG-3'); $\beta$-actin (sense: $5^{\prime}$-TGTGATGGTGGGAATGGGTCAG-3' , antisense: $5^{\prime}$-TTTGATGTCACGCACGATTTCC-3'). PCR products were visualized by ethidium bromide staining in $1.5 \%$ agarose gel and quantified using Gel-Pro Analyzer software (Media Cybernetics). All experiments were replicated at least three times.

Relative quantification of gene expression was conducted with the ABI Prism 7500 sequence detector (Applied Biosystems Inc). PCR results 
were normalized to the expression of $\beta$-actin. Real-time PCR primers for mFPR2 were as follows: $5^{\prime}$-CATGGGCCAGGACTTTCGT-3' (sense) and 5'-TGGTGCTTGAATCACTGGTTTG-3' (antisense). Mouse $\beta$-actin primers were: $5^{\prime}$-CAACGAGCGGTTCCGAT- $3^{\prime}$ (sense); and 5'-GCCACAGGATTCCATACCCA-3' (antisense).

Intracerebroventricular injection. Male C57BL/6 mice ( 8 weeks old) were used in the study. Animals were anesthetized with chloral hydrate $(0.18 \mathrm{ml}$ of $6 \%$ chloral hydrate per mouse $)$ and immobilized in a stereotaxic apparatus, and the skulls were exposed for trepanation. Five microliters of $1 \mu \mathrm{M} \mathrm{NE}(n=6)$ or the same volume of PBS ( $n=7)$ was injected into the lateral ventricle. Coordinates were determined according to a mouse stereotactic atlas as follows: $-1 \mathrm{~mm}$ posterior, $1 \mathrm{~mm}$ lateral, $1.7 \mathrm{~mm}$ ventral to bregma. After $24 \mathrm{~h}$, mice were killed by cervical dislocation. The brains were removed, washed in PBS, and homogenized in TRIzol reagent. RNA was extracted and examined for mFPR2 mRNA level by real-time PCR.

Calcium mobilization assay. $\mathrm{Ca}^{2+}$ mobilization was measured with FlexStation II $^{384}$ system (Molecular Devices) as described previously (Zhu et al., 2009). Briefly, N9 cells were loaded with Fura-3 AM, washed, and resuspended in emission buffer at a density of $4 \times$ $10^{6}$ cells/L for $15 \mathrm{~min}$. The fluorescence before and after the addition of different concentrations of $\mathrm{W}$ peptide was measured with the excitation wavelength at $485 \mathrm{~nm}$ and the emission wavelength at $525 \mathrm{~nm}$ and presented as relative fluorescence units (RFU).

mFPR2 short hairpin RNA constructs, transfection, and virus transduction. To construct mFPR2 short hairpin RNA (shRNA) expression plasmid, two complementary mFPR2 DNA oligos (see below) were synthesized, annealed, and inserted between BbsI and XhoI sites of the plasmid pBS-hU6-I. The fragment containing human U6-RNA Pol III promoter and $\mathrm{mFPR} 2$ shRNA then were subcloned into FG12 between the XbaI and XhoI sites. FG12 vector also expresses a human UbiC-driven green fluorescent protein (GFP) gene to provide a marker for tracking transduced cells. The resulting plasmids were confirmed by restriction enzyme digestion and DNA sequencing. mFPR2 target sequences are nucleotides 297-315 (ATTAGTTCACATTGTGGTA) (shRNA-a), 537-555 (CTTTGGATCCTGGGCTCAA) (shRNA-b), and 836-854 (TTCTTGACATGTTTGTTAA) (shRNA-c) of mouse FPR2 mRNA (GeneBank accession no. NM 008039). BLAST (Basic Local Alignment Search Tool) search against mouse genome sequences confirmed that only mFPR2 gene was targeted. Recombinant lentiviruses were produced by transient transfection of HEK293T cells with lentiviral mFPR 2 shRNA vector, the lentiviral packaging constructs $\mathrm{pRSV} / \mathrm{REV}$ and $\mathrm{pMDLG} / \mathrm{pRRE}$, and the vesicular stomatitis virus glycoprotein (VSVG)-expressing plasmid pHCMVG using the calcium phosphate method, as described previously (Tiscornia et al., 2006). mFPR2/293 cells and N9 cells were transduced with concentrated lentivirus stocks at the same multiplicity of infection in the presence of $4 \mu \mathrm{g} / \mathrm{ml}$ polybrene. After $3 \sim 7$ days, GFP-positive cells were sorted by fluorescence-activated cell sorter and kept growing for future use.

Chemotaxis assay. Chemotaxis assays for N9 cells pretreated with 10 $\mu \mathrm{M}$ ISO or $500 \mathrm{ng} / \mathrm{ml}$ lipopolysaccharide (LPS) for $24 \mathrm{~h}$ and mFPR2/293 cells transduced with control lentiviruses or mFPR2 shRNA lentiviruses peptide.

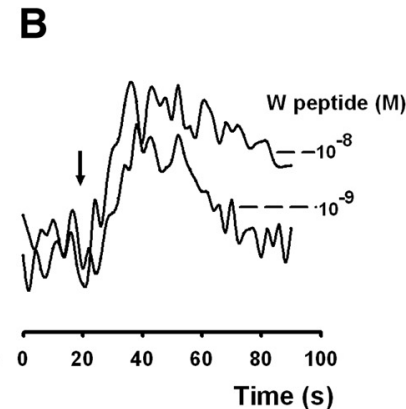

C ISO

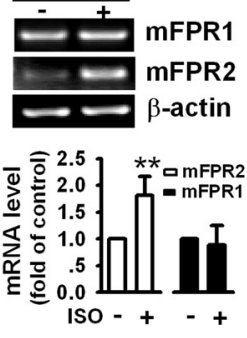

E
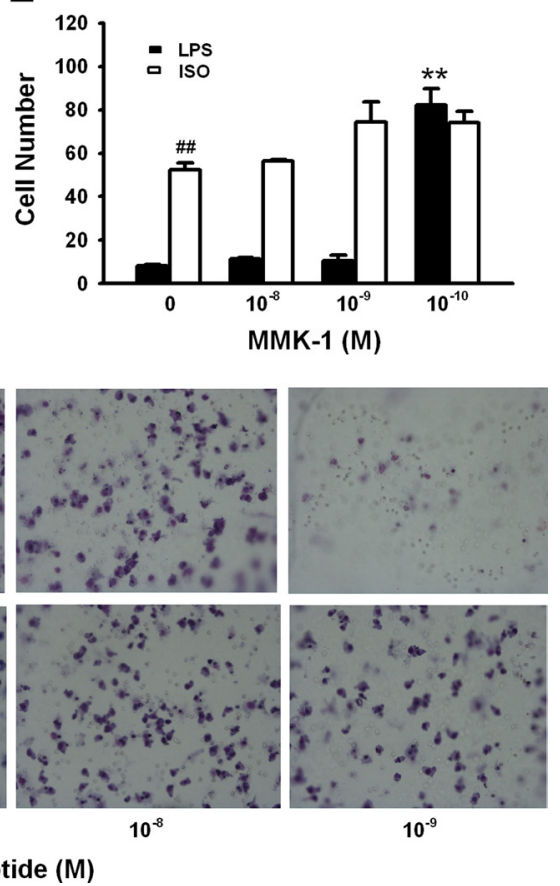

$10^{-9}$

W peptide (M)

Figure 3. Isoproterenol treatment of microglia increases calcium mobilization but not cell migration in response to $\mathrm{mFPR2}$ gonists. $\boldsymbol{A}-\boldsymbol{C}$, N9 cells were treated with or without $40 \mu \mathrm{m}$ ISO for $24 \mathrm{~h}$ and then loaded with Fura-3-AM and stimulated with

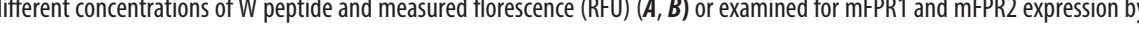
cultured in the peptide $(\boldsymbol{D})$, and MMK-1 $(\boldsymbol{E})$. The results are expressed as the mean \pm SD of migrated cells in three high-power fields in triplicate spontaneous cell migration between N9 cells treated with ISO and LPS. $\boldsymbol{F}$, Visualization of N9 cell migration in response to W

were performed with 48-well chemotaxis chambers (NeuroProbe) as described previously (Cui et al., 2002a). Polycarbonate filters ( $8 \mu \mathrm{m}$ pore size, incubated for $90 \mathrm{~min}$ at $37^{\circ} \mathrm{C}$ ) were used for measurement of $\mathrm{N} 9$ cell migration. For mFPR2/293 cells, $10 \mu \mathrm{m}$ pore size, collagen type I-coated filters (incubated for $4 \mathrm{~h}$ ) were used. The results are expressed as the mean $\pm \mathrm{SD}$ of migrated cells in three high-power fields in triplicate samples or as chemotaxis index, which represents the fold increase in the number of migrated cells in response to chemoattractants over the spontaneous cell migration (to control medium).

Immunofluorescence confocal microscopy. N9 cells or primary microglia grown on slides in a 24 -well plate were treated with $10 \mu \mathrm{M} \mathrm{ISO}$ at $37^{\circ} \mathrm{C}$ for $24 \mathrm{~h}$, followed by treatment with or without $10 \mu \mathrm{M} \mathrm{A} \beta_{42}$ for $30 \mathrm{~min}$, and then fixed in $4 \%$ paraformaldehyde for $10 \mathrm{~min}$ at room temperature. Slides were washed with PBS and incubated with 5\% BSA in PBS with $0.05 \%$ Tween 20 at room temperature for $1 \mathrm{~h}$ to reduce nonspecific binding of antibodies to the cell surface and for cell permeabilization. A mouse anti-A $\beta$ antibody was applied to the slides and incubated overnight at $4^{\circ} \mathrm{C}$. The slides were washed and incubated with Alexa Fluor 

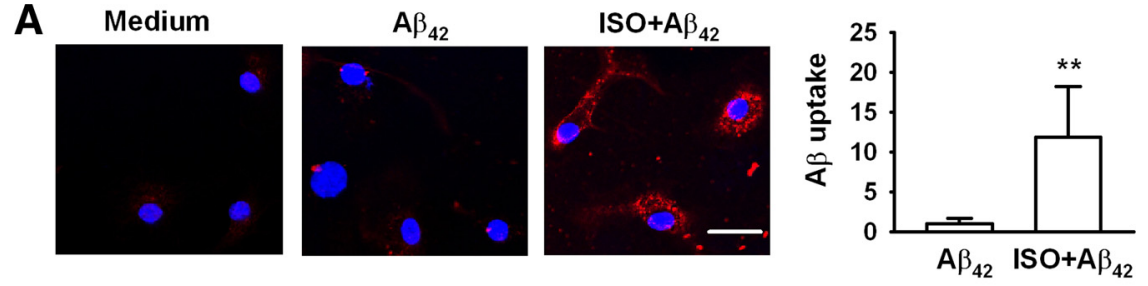

B

C
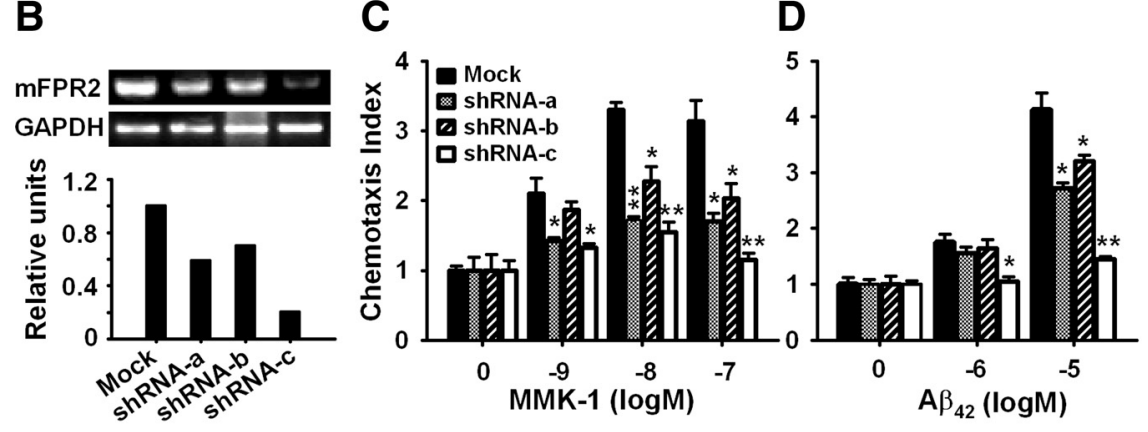

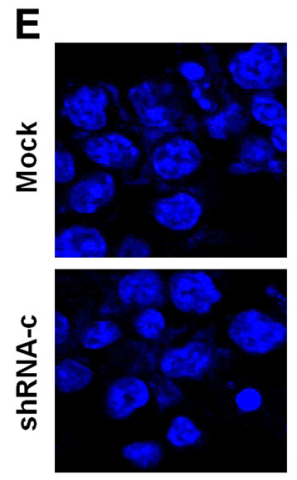

Medium
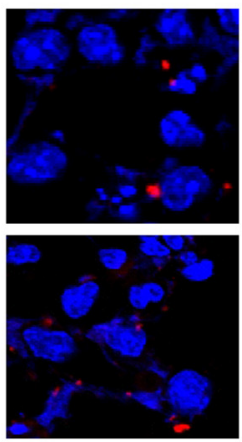

$\mathrm{A} \beta_{42}$
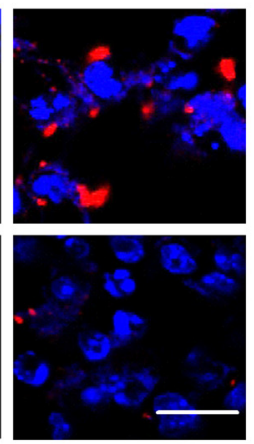

$\mathrm{ISO}+\mathrm{A} \beta_{42}$

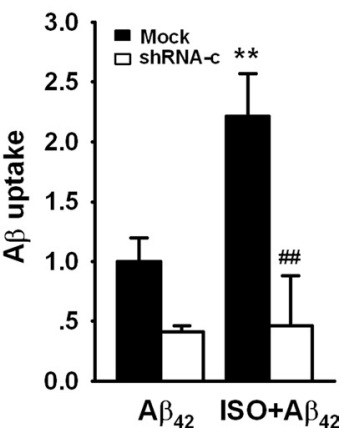

Figure 4. Isoproterenol enhances $A \beta_{42}$ uptake by microglia. $\boldsymbol{A}, \boldsymbol{E}$, Primary microglia $(\boldsymbol{A})$, N9 cells $(\boldsymbol{E})$ transduced with control lentivirus (Mock), or mFPR2 shRNA-c lentivirus (shRNA-c) were treated with or without $10 \mu \mathrm{m} I S O$ for $24 \mathrm{~h}$ followed by incubation with $10 \mu \mathrm{MA} \beta_{42}$ for 30 min and then examined for $A \beta$ uptake with antibody against $A \beta$ (red). Nuclei were stained with Hoechst (blue). Scale bars, $20 \mu \mathrm{m}$. Dara are expressed as mean $\pm S D\left(n=2\right.$, with duplicate samples in each experiment); ${ }^{* *} p<0.01$, compared with $A \beta$ uptake by primary microglia or mock transduced $N 9$ cells without I $S 0$ treatment; ${ }^{\# \#} p<0.01$, compared with $A \beta$ uptake by mock transduced N9 cells pretreated with ISO. $\boldsymbol{B}-\boldsymbol{D}, \mathrm{mFPR} 2 / 293$ cells were transduced with control lentiviruses (Mock) or mFPR2 shRNA lentiviruses, mFPR2 mRNA level was examined by RT-PCR $(\boldsymbol{B})$, and cell migration in response to mFPR2 agonists (C: MMK-1; $\left.\mathbf{D}: \mathbf{A} \beta_{42}\right)$ was examined by chemotaxis assay. Data are expressed as mean $\pm \mathrm{SD}(n=3) ;{ }^{*} p<0.05$, ${ }^{* *} p<$ 0.01 , chemotaxis index of mFPR2 shRNA lentivirus transduced cells versus control lentivirus transduced cells (Mock).

conjugated secondary antibody, the protein bands were detected with a SuperSignal West Pico chemiluminescent substrate (Pierce) and X-Omat BT film (Eastman Kodak).

Statistics. The significance of the difference between test and control groups was analyzed with Student's $t$ test, and $p$ values $\leq 0.05$ were considered statistically significant.

\section{Results}

Norepinephrine and isoproterenol upregulate $\mathrm{mFPR} 2$ expression through activation of $\boldsymbol{\beta}_{2} \mathrm{AR}$

Human $\mathrm{G}$ protein-coupled receptor FPR2 and its mouse homolog mFPR2 have been reported to be the receptor for $\mathrm{A} \beta_{42}$. FPR2/mFPR2 mediates the internalization of $\mathrm{A} \beta_{42}$ by microglia (Yazawa et al., 2001; Iribarren et al., 2005; Chen et al., 2006). We first checked the effect of NE and $\beta$ AR agonist ISO on mFPR 2 mRNA expression in N9 cells by real-time PCR. As shown in Figure 1, NE (Fig. 1 $A$ ) and ISO (Fig. $1 C$ ) both upregulated mFPR2 mRNA level in a dose-dependent manner. The inductive effect of these two compounds on mFPR2 expression was also confirmed in mouse primary microglia (Fig. $1 B, D$ ). In $\mathrm{C} 57 \mathrm{BL} / 6$ mice injected with $1 \mu \mathrm{M} \mathrm{NE}$ in the lateral ventricle (5 $\mu \mathrm{l} /$ mouse, $n=6$ ), the mFPR2 mRNA level in brain at $24 \mathrm{~h}$ after injection was elevated to $1.40 \pm 0.29$-fold $(p=0.02)$ of control mice injected with same volume of PBS $(n=7)$, demonstrating the upregulation of $\mathrm{mFPR} 2$ expression by $\mathrm{NE}$ in vivo.

To investigate the involvement of $\beta \mathrm{AR}$ in the upregulation of $\mathrm{mFPR} 2$ by $\mathrm{NE}$ and ISO, we examined the expression of $\beta A R$ in N9 cells and primary microglia by RTPCR. The results showed that both N9 cells and primary microglia express $\beta_{2}$ AR but not $\beta_{1}$ and $\beta_{3}$ ARs (Fig. $2 A$ ).

546-conjugated goat anti-mouse IgG (Invitrogen) for $60 \mathrm{~min}$, washed in PBS, stained with Hoechst 33342, and mounted. Immunofluorescence labeling was observed under a laser scanning confocal microscope (LSM 510 META, Zeiss). Cells in three high-power fields (each includes $\sim 40$ cells) were quantified for amyloid uptake by using ImageJ program (http://rsbweb.nih. gov/ij).

Immunoblot analysis. Western blotting was performed as described previously (Wang et al., 2008). The following primary antibodies were used: antibodies against total or phosphorylated ERK1/2, p38, JNK, I $\kappa \mathrm{B} \alpha$; antibodies against neprilysin and IDE. Primary antibodies were recognized by HRP-conjugated secondary antibodies. Immunoblot results were quantified by using Gel-Pro Analyzer software (Media Cybernetics).

To examine $\mathrm{A} \beta_{42}$ uptake and degradation by $\mathrm{N} 9$ cells and murine primary microglia, $\mathrm{A} \beta_{42}$ was oligomerized as described previously (Tahara et al., 2006). After treatment of the cells with $A \beta_{42}$ for $12 \mathrm{~h}, \mathrm{~A} \beta$ level in the supernatant and cell lysate was detected by Western blot as described previously (Schägger, 2006). Briefly, $20 \mu \mathrm{l}$ of supernatant or 50 $\mu \mathrm{g}$ of cell lysate were boiled for $5 \mathrm{~min}$ and underwent Tris-Tricine SDSPAGE and electrotransferred to polyvinylidene difluoride membranes (Immobilon-P, Millipore). The membrane was blocked with 5\% nonfat milk and then incubated with anti-A $\beta$ antibody (6E10), or anti-actin monoclonal antibody overnight at $4^{\circ} \mathrm{C}$. After incubation with HRP-
Pretreatment of N9 cells with the $\beta_{1,2} \mathrm{AR}$ antagonist propranolol significantly inhibited the inductive effect of NE and ISO on mFPR2 expression (Fig. $2 B$ and $C$ ), suggesting that NE and ISO upregulate mFPR 2 through activation of $\beta_{2} \mathrm{AR}$.

We then checked whether the MFPR 2 upregulated by isoproterenol is functional. Calcium mobilization is a signaling event of mFPR2 activation (Tiffany et al., 2001). N9 cells without ISO treatment had no response to $\mathrm{W}$ peptide, a ligand for $\mathrm{mFPR} 2$ (Fig. 3A). However, after treatment of N9 cells with ISO for $24 \mathrm{~h}$, $\mathrm{W}$ peptide induced a robust and transient calcium flux (Fig. $3 B$ ). Although W peptide is also reported to be an agonist for mFPR1 (He et al., 2000), ISO had no significant effect on mFPR1 expression in N9 cells (Fig. 3C). These results indicate that mFPR2 induced by ISO could mediate cell response to FPR2 ligand. Together, the above results demonstrated that activation of $\beta_{2} \mathrm{AR}$ on mouse microglia could increase the expression of mFPR 2 and its response to agonist. As N9 cells and primary microglia both only express $\beta_{2} \mathrm{AR}$ and respond to NE and ISO in a similar way, we used ISO to treat microglia in most of the following experiments. 
As NE and ISO have been reported to enhance microglial cell migration (Heneka et al., 2010), we then examined whether these compounds promote cell migration through upregulation of mFPR2. We found that pretreatment of N9 cells with ISO significantly increased spontaneous cell migration but had no significant effect on cell migration in response to $\mathrm{W}$ peptide (Fig. $3 D, F$ ) and MMK-1 (Fig. 3E), a potent $\mathrm{mFPR} 2$ agonist derived from random peptide library ( $\mathrm{Hu}$ et al., 2001). As positive control, pretreatment of N9 cells with LPS significantly augmented cell migration in response to $\mathrm{W}$ peptide and MMK-1, confirming our previous report that LPS increases microglial cell migration to $\mathrm{mFPR} 2$ agonists through upregulation of mFPR2 expression (Cui et al., 2002a). These results suggest that activation of $\beta_{2} \mathrm{AR}$ on microglia enhance cell migration independently of mFPR2.

Isoproterenol enhances $\mathrm{A} \boldsymbol{\beta}_{42}$ uptake by microglia through mFPR2

The effect of ISO on A $\beta$ uptake by microglia was examined by immunofluorescence confocal microscopy. We found that ISO treatment could significantly increase the internalization of $\mathrm{A} \beta_{42}$ in primary murine microglia (Fig. $4 A$ ) and N9 cells (data not shown) after incubation with $\mathrm{A} \beta_{42}$ for $30 \mathrm{~min}$. These results were consistent with previous reports (Kalinin et al., 2007; Heneka et al., 2010).

To examine whether $\beta_{2} \mathrm{AR}$ activation enhances the capability of microglia to uptake $\mathrm{A} \beta$ through upregulation of FPR2, we used a RNA interference technique to inhibit mFPR2 expression. Three lentiviral mFPR2 shRNA expression vectors targeting the 297-315 (shRNA-a), 537-555 (shRNA-b), and 836-854 (shRNA-c) regions of mFPR2 coding sequence were constructed. mFPR2/293 cells transduced with various mFPR2 shRNA lentiviruses inhibited $\mathrm{mFPR} 2$ expression at $\mathrm{mRNA}$ and protein levels with different potency (Fig. $4 B$ and data not shown). The inhibitory effect of mFPR2 shRNA-c is the most potent. To determine whether expression of mFPR 2 shRNA could induce functional silencing of mFPR2, we examined the effect of mFPR2 shRNA on chemotactic response to mFPR2 agonists. mFPR2/293 cells expressing mFPR2 shRNA-c showed a markedly reduced chemotactic response to MMK-1 (Fig. $4 C$ ) and $\mathrm{A} \beta_{42}$, the major component of amyloid plaque in AD brain (Fig. 4D). mFPR2 shRNA-a and mFPR2 shRNA-b showed certain levels of attenuation of agonistinduced cell migration, albeit with lower efficacy compared with mFPR2 shRNA-c (Fig. 4C,D). Thus, mFPR2 shRNA-c is a selective and highly efficacious mFPR2 shRNA-expressing vector that attenuates both mFPR2 expression and its key function. It was used in the next experiments.

Similar to the results from primary microglia, treatment of control lentivirus-transduced N9 cells with $10 \mu \mathrm{M}$ ISO markedly increased the uptake of $\mathrm{A} \beta_{42}$ (Fig. $4 E$, top). However, transduc-
B
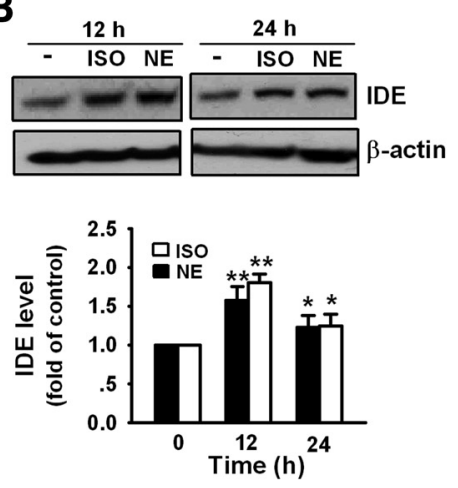

E

D

$-\quad+150$

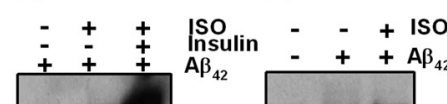

$\mathbf{F}$

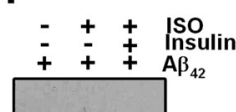

Figure 5. Activation of $\beta_{2} A$ R on microglia cells increases the protein level of IDE and enhances $A \beta$ degradation. $A$, N9 cells were treated with $10 \mu \mathrm{M}$ ISO for 12 and $24 \mathrm{~h}$ and cell lysates were subjected to immunoblot analysis with antibodies against IDE, IDE expression lysate and supernatant with Western blot. Data are the mean $\pm \mathrm{SD}(n=3) ;{ }^{* *} p<0.01$, compared with $\mathrm{A} \beta$ in cells treated with
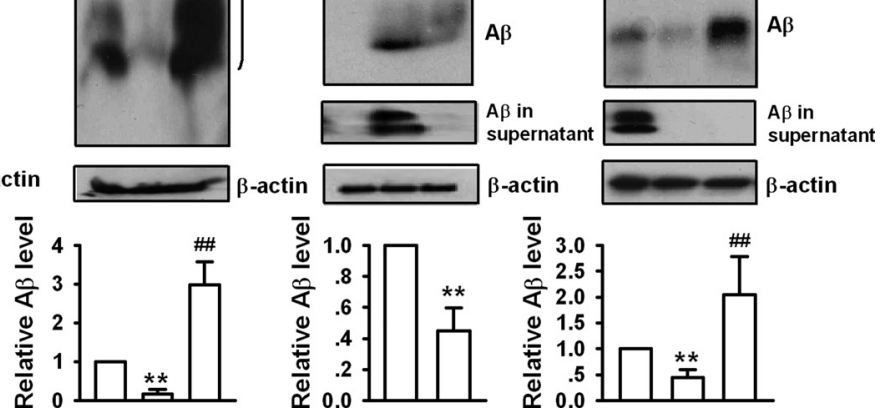
A
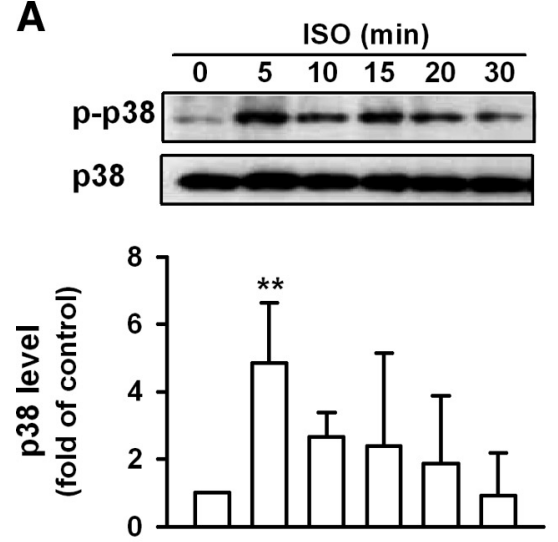

C
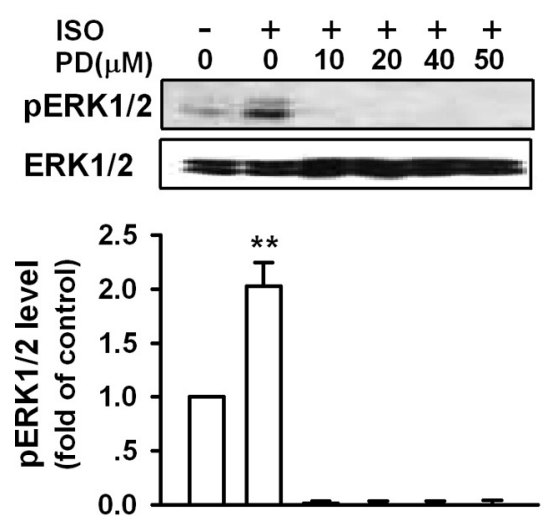

B
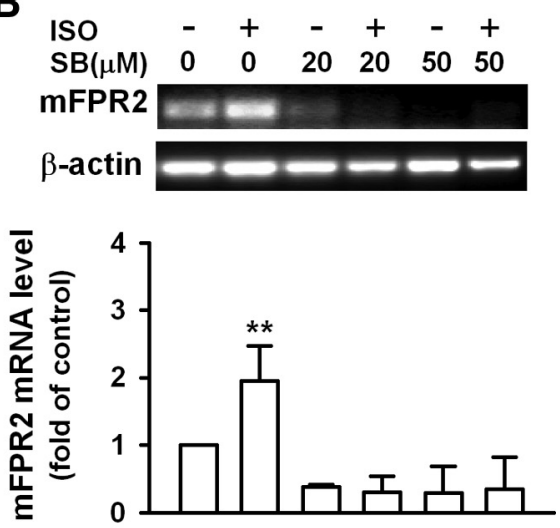

D
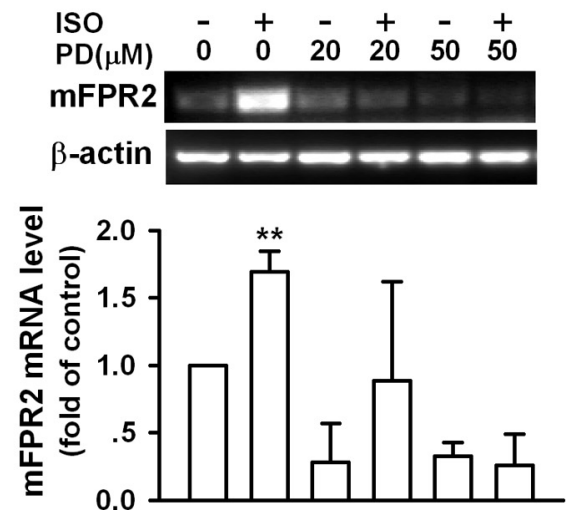

Figure 6. Isoproterenol induces mFPR2 mRNA expression in microglia through activation of MAP kinases. N9 cells were treated with $10 \mu \mathrm{M}$ ISO for different periods of time $(\boldsymbol{A})$ or treated with or without different concentrations of PD98059 (PD) (C) for $1 \mathrm{~h}$ followed by $10 \mu \mathrm{m}$ ISO for 30 min and then examined for $\mathrm{p} 38$ or ERK1/2 phosphorylation by Western blot. N9 cells pretreated with different concentrations of SB203580 (SB) (B) or PD (D) for $1 \mathrm{~h}$ were stimulated with or without $10 \mu \mathrm{m}$ ISO for $9 \mathrm{~h}$ and then examined for mFPR2 mRNA level by RT-PCR. All data are mean $\pm S D(n=3)$; ${ }^{* *} p<0.01$, compared with cells without stimulation.

Intracellular aggregates of $\mathrm{A} \beta$ were readily detectable in the cell lysate from N9 cells (Fig. 5C,D) and primary microglia (Fig. $5 E, F)$. Pretreatment of N9 cells and primary microglia with ISO for $24 \mathrm{~h}$ significantly decreased $\mathrm{A} \beta$ in supernatant and cell lysate (especially the low molecular weight aggregates). These results, together with data in Figure 4, $A$ and $E$, demonstrated that activation of $\beta_{2} \mathrm{AR}$ on microglia promoted $\mathrm{A} \beta$ uptake and degradation. We further evaluate the contribution of IDE and neprilysin to ISO-induced A $\beta$ degradation. Treatment of N9 cells (Fig. 5D) or primary microglia (Fig, $5 F$ ) with insulin, a competitive inhibitor of IDE, significantly inhibited ISO-induced $\mathrm{A} \beta$ clearance, suggesting ISO enhances $A \beta$ degradation through induction of IDE. However, neprilysin inhibitor phosphoramidon could not suppress ISO-induced A $\beta$ clearance in both N9 cells and primary microglia (data not shown). Together, activation of $\beta_{2} \mathrm{AR}$ on microglia promoted $\mathrm{A} \beta$ uptake and degradation by upregulating the expression and function of $\mathrm{MFPR} 2$ and IDE, respectively.

\section{Isoproterenol induces FPR2 mRNA expression in microglia through MAP kinases and NF- $\kappa \mathrm{B}$}

We further explored the mechanisms underlying FPR2 upregulation by $\beta_{2} \mathrm{AR}$ activation. Because the MAPK (mitogen-activated protein kinase) pathway has been implicated in the induction of mFPR2 in microglial cells via activation of TLR4 by LPS (Cui et al., 2002a) and MAP kinases are downstream signaling molecules of $\beta$ AR activation (Liu et al., 2006; Gong et al., 2008; Qian et al., 2009), we assessed the role of MAPKs in ISO induction of mFPR2 in microglial cells. As shown in Figure $6 A$, ISO induced a rapid and potent phosphorylation of $\mathrm{p} 38$ MAPK in N9 cells. In cells pretreated with SB203580, a p38 MAPK inhibitor, the level of mFPR2 mRNA induced by ISO was significantly reduced (Fig. 6B). ISO additionally induced increased phosphorylation of ERK1/2, and the MEK (MAPK kinase) inhibitor PD98059 dose-dependently inhibited ERK1/2 phosphorylation and mFPR2 expression induced by ISO (Fig. $6 C, D)$. Although ISO also induced JNK phosphorylation in N9 cells, JNK inhibitor SP600125 had no effect on ISOinduced mFPR2 expression (data not shown). These results indicate that MAPKs p38 and ERK1/2 play an essential role in ISO induction of the $\mathrm{mFPR} 2$ gene in mouse microglial cells.

$\mathrm{NF}-\kappa \mathrm{B}$ has been reported to mediate peptidoglycan-induced mFPR2 expression in microglial cells (Chen et al., 2006). $\mathrm{NF}-\kappa \mathrm{B}$ is also a molecule of $\beta \mathrm{AR}$ signaling pathway (Takemoto et al., 1999; Chandrasekar et al., 2004). We analyzed the sequence of the promoter region of $\mathrm{mFPR} 2$ and found the existence of NF- $\kappa \mathrm{B}$ binding sites. Pretreatment of N9 cells with a highly selective $\mathrm{I} \kappa \mathrm{B} \alpha$ phosphorylation inhibitor, BAY117082, significantly inhibited ISO-induced mFPR2 expression (Fig. 7A). Consistently, stimulation of N9 cells and primary microglia with ISO markedly increased $\mathrm{I} \kappa \mathrm{B} \alpha$ phosphorylation (Fig. $7 B, C)$ and $\mathrm{I} \kappa \mathrm{B} \alpha$ degradation (Fig. $7 D$ ). These results suggest that $\mathrm{NF}-\kappa \mathrm{B}$ is an important transcription factor that mediated the upregulation of mFPR2 expression by ISO. Pretreatment of N9 cells with BAY117082 reversed ISO-induced $\mathrm{I} \kappa \mathrm{B} \alpha$ degradation (Fig. 7D). Pretreatment of N9 cells with PD98059 or SB203580 also reversed $\mathrm{I} \kappa \mathrm{B} \alpha$ degradation induced by ISO, suggesting that ERK1/2 and p38 are upstream signaling molecules mediating ISO-induced NF- $\kappa \mathrm{B}$ activation. Together, these results suggest that ISO induces mFPR2 expression through $\mathrm{p} 38-\mathrm{NF}-\kappa \mathrm{B}$ and ERK1/2-NF- $\kappa$ B signaling pathways.

\section{Discussion}

In this study, we demonstrated that NE and ISO could induce mFPR2 mRNA expression in microglial cells through $\beta_{2} \mathrm{AR}$ mediated activation of MAP kinases ERK1/2 and p38, as well as transcription factor NF- $\kappa \mathrm{B}$. Upregulation of mFPR2 expression by $\beta_{2} \mathrm{AR}$ activation in microglia markedly enhanced $\mathrm{A} \beta_{42}$ uptake. We also found that activation of $\beta_{2} \mathrm{AR}$ in microglia increased the expression of $A \beta$-degrading enzyme IDE and enhanced the degradation of $\mathrm{A} \beta_{42}$.

Microglia are resident brain mononuclear phagocytes and have functions similar to peripheral macrophages. They play a critical role as resident immunocompetent and phagocytic cells in the CNS and serve as scavenger cells in the event of infection, inflammation, trauma, ischemia, and neurodegeneration 
A

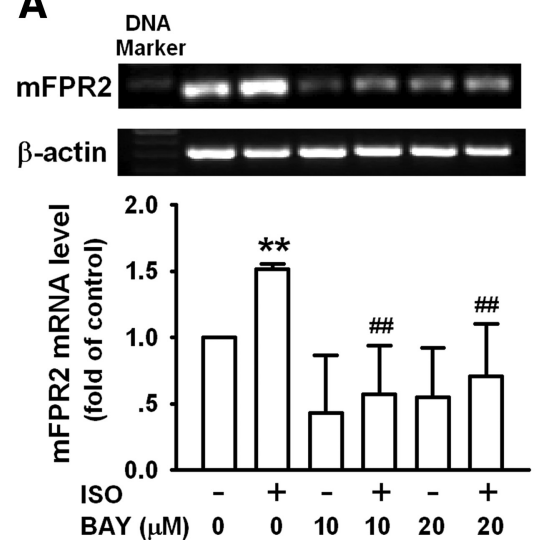

B

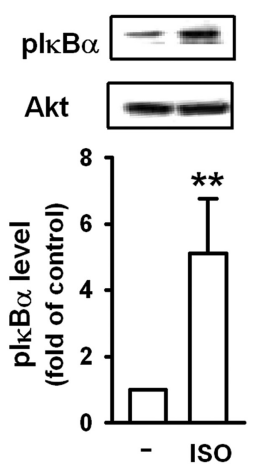

C
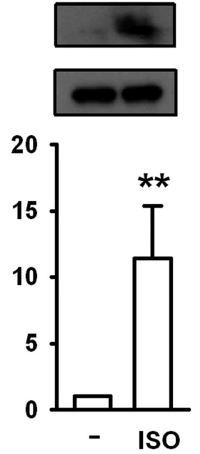

D
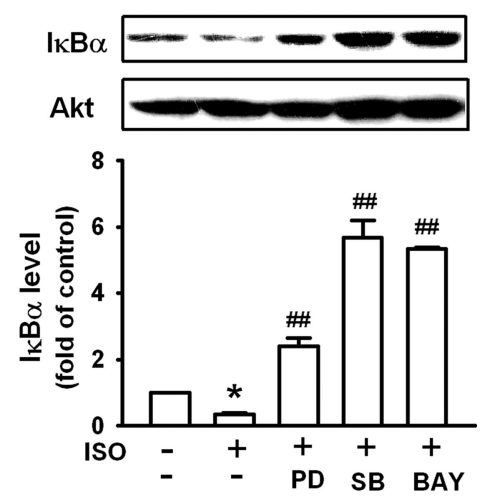

Figure 7. Isoproterenol induces mFPR2 mRNA expression through ERK/p38-NF- $\kappa B$ pathway. $A$, N9 cells pretreated with or without different concentrations of BAY117082 (BAY) for $1 \mathrm{~h}$ were stimulated with $10 \mu \mathrm{m} \mathrm{ISO} \mathrm{for} 9 \mathrm{~h}$ and then examined for mFPR2 expression by RT-PCR. $\boldsymbol{B}, \boldsymbol{C}, \mathrm{N} 9$ cells ( $\boldsymbol{B}$ ) or primary microglia ( $\boldsymbol{C}$ ) were stimulated with $10 \mu \mathrm{m}$ ISO for 30 min and then examined for I $\kappa B \alpha$ phosphorylation by Western blot. D, N9 cells pretreated with or without $50 \mu \mathrm{m}$ PD98059 (PD), $50 \mu \mathrm{m}$ SB203580 (SB), or $20 \mu \mathrm{m}$ BAY for $1 \mathrm{~h}$ were stimulated with $10 \mu \mathrm{m}$ ISO for 30 min and then examined for $\mathrm{I}_{\kappa} \mathrm{B} \alpha$ level by Western blot. All data are mean $\pm \mathrm{SD}(n=3) ;{ }^{*} p<0.05,{ }^{* *} p<0.01$, compared with cells cultured in medium alone; ${ }^{\# \#} p<0.01$, compared with cells treated with ISO alone.

(Kreutzberg, 1996; González-Scarano and Baltuch, 1999; Aloisi et al., 2001). Although microglial activation has become increasingly regarded as a contributor to $\mathrm{AD}$ pathogenesis by producing neurotoxins including reactive oxygen species and proinflammatory cytokines, it also plays a neuroprotective role in AD by secreting proteolytic enzymes that degrade $A \beta$ and express receptors that are involved in the endocytosis and clearance of $\mathrm{A} \beta$. The notion that microglia actively uptake $\mathrm{A} \beta$ peptide is supported by experiments using in vitro culture (Frackowiak et al., 1992; Pocock et al., 2002) and animal AD models (Frautschy et al., 1998; Weldon et al., 1998). In mouse AD models, active immunization with A $\beta$ peptide (Schenk et al., 1999; Lombardo et al., 2003) or passive immunization with antibodies to $A \beta$ (Wilcock et al., 2003) resulted in substantial removal of existing A $\beta$ deposits, apparently by microglia. A series of cell membrane receptors has been reported to be able to meditate binding and endocytosis of $\mathrm{A} \beta$, including $\mathrm{G}$ protein-coupled receptor formyl peptide receptor 2 , scavenger receptors, receptor of advanced glycation end products, Fc receptors, complement receptors, and CD14 (Paresce et al., 1996; Yan et al., 1996; Bard et al., 2000; Webster et al., 2000; Le et al., 2001; Liu et al., 2005). Human FPR2, also called formyl peptide receptor-like 1, is encoded by a gene that shares homology to the human formyl peptide receptor (FPR1) gene. FPR2 was initially known for its low-affinity interaction with formyl-methionyl-leucyl phenylalanine, the highaffinity agonist for FPR1. Subsequent studies have identified many agonists for this receptor, including microbe- and hostderived peptides, lipoxin A4, synthetic peptides, and nonpeptide agonists (Le et al., 2002; Ye, 2009; Ye et al., 2009). Although FPR2 was initially detected in phagocytic leukocytes, other cell types also express this receptor, such as microglia and astrocytes (Le et al., 2002). $\mathrm{A} \beta_{42}$, the key causative factor in $\mathrm{AD}$, has been reported to activate microglia through human FPR2 or its mouse homolog mFPR2 (Le et al., 2001; Tiffany et al., 2001; Yazawa et al., 2001). The amount of FPR2 expressed on the cell surface is regulated through receptor internalization and mobilization from intracellular pools as well as at the transcriptional level (Ye, 2009). For example, the cell surface number of FPR2 is regulated by ligandinduced receptor internalization; stimulation of neutrophils with several agonists that induce degranulation upregulates the FPR2mediated response to WKYMVm; differentiated HL-60 cells ex- press more FPR2 transcript than undifferentiated HL-60 cells. IL-13 and interferon- $\gamma$ stimulate the expression of FPR2 in enterocytes. We previously reported that murine microglial cells in the nonstimulated state express low levels of mFPR2 (Cui et al., 2002a) which are upregulated by pathogen-associated molecular patterns and proinflammatory cytokines, such as LPS, TNF- $\alpha$, PGN, CpG, IFN- $\gamma$ and CD40 (Cui et al., 2002a,b; Iribarren et al., 2005; Chen et al., 2006; 2007). The upregulation of mFPR2 was associated with a markedly increased microglial chemotaxis to $\mathrm{A} \beta_{42}$ and its endocytosis via mFPR2. These results suggest that mFPR2 in microglia not only mediates the proinflammatory activity of $\mathrm{A} \beta_{42}$ but also may actively participate in the clearance of the amyloid $\beta$ peptide. Our present study reveals that NE, the endogenous neurotransmitter mainly produced by LC neurons, is able to induce the expression of mFPR2 and promote $\mathrm{A} \beta$ uptake by microglia. The inductive effect of NE on mFPR2 expression is mediated by MAPK-NF- $\kappa \mathrm{B}$ signaling pathways.

Neurons can influence microglial functions through direct cell-to-cell interactions as well as with the release of soluble mediators. Microglial processes have been reported to be associated with synapses anatomically (Pow et al., 1989), and microglia may also respond to "volume neurotransmission" (Thomas, 1992), in which transmitters may exist and act extrasynaptically. Among signals from neurons that may have an active role in controlling microglial activation are those from two major neurotransmitters: NE and acetylcholine (Carnevale et al., 2007). NE has been reported to be a potent regulator of microglial function. Activation of $\beta A R$ in microglia has been shown to be capable of inhibiting inflammatory responses induced by various stimuli, including $\mathrm{A} \beta$, IFN $\gamma$, and LPS (Loughlin et al., 1993; Mori et al., 2002; Dello Russo et al., 2004; Färber et al., 2005; Madrigal et al., 2005; Heneka et al., 2010). Meanwhile, both in vitro and in vivo studies have demonstrated that $\beta \mathrm{AR}$ activation induces proinflammatory cytokine expression in microglia (Tomozawa et al., 1995; Chandrasekar et al., 2004; Johnson et al., 2005; Blandino et al., 2006). NF- $\kappa \mathrm{B}$ has been reported to be involved in both of the anti-inflammatory and proinflammatory effects of $\beta$ AR agonists (Farmer and Pugin, 2000; Chandrasekar et al., 2004). These results suggest that $\beta \mathrm{AR}$ activation may exert anti-inflammatory and proinflammatory effects under different circumstances. Rat primary microglia express $\beta_{1}$ and $\beta_{2}$ ARs but not $\beta_{3} \mathrm{AR}$ (Tanaka et 
al., 2002). Our results showed that only $\beta_{2} \mathrm{AR}$ could be detected in both primary mouse microglia and N9 cells. Supporting our results, Hertz et al. (2010) examined the expression of $\beta$ AR subtypes in acutely isolated murine microglia by microarray and found that microglia mainly express $\beta_{2}$ AR. Our results demonstrated that NE and ISO upregulated the expression of mFPR 2 in murine microglia and enhanced the uptake and clearance of $\mathrm{A} \beta_{42}$ through the activation of $\beta_{2} \mathrm{AR}$, and ISO enhanced microglial cell migration independent of mFPR2. Thus, NE acts as a link between neuron and microglia to orchestrate the host responses to $\mathrm{A} \beta$ in the pathogenesis of $\mathrm{AD}$.

$\mathrm{A} \beta$ is produced continuously in brain, and its concentration is determined in part by the activities of several degradative enzymes, including neprilysin, IDE, ECE-1 (endothelin-converting enzyme 1) and ECE-2, and probably plasmin (Leissring et al., 2003; Eckman and Eckman, 2005). IDE mRNA and protein levels in hippocampus were significantly decreased in apolipoprotein $\mathrm{E}$ $\varepsilon 4^{+} \mathrm{AD}$ patients (Cook et al., 2003). In AD mouse models, the expression levels of neprilysin and IDE in microglia were decreased in 14-month-old mice (Hickman et al., 2008). Recent studies demonstrated that IDE expression and activity were complexly regulated by various factors, including aging, Apo E, cytokines, and vitamin E (Eckman and Eckman, 2005; Jiang et al., 2008; Shimizu et al., 2008; Nishida et al., 2009). Therefore, the upregulation of IDE represents a promising strategy for therapy and prevention for AD. Our results showed that NE and ISO could induce IDE expression and promote $A \beta$ degradation through activation of $\beta_{2} \mathrm{AR}$ in primary microglia. To our knowledge, this is the first report demonstrating that the endogenous neurotransmitter NE plays an important role in maintaining expression and activity of IDE in microglia, which contribute to A $\beta$ clearance in brain.

LC neuron degeneration-induced NE deficiency has been linked to more severe brain lesions in both AD patients and animal models (Bondareff et al., 1987; Heneka et al., 2002). In this study we found that by activation of $\beta_{2} \mathrm{AR}$ in microglia, NE enhanced $\mathrm{A} \beta$ uptake through upregulation of mFPR 2 and increased $\mathrm{A} \beta_{42}$ clearance through induction of IDE. These results suggest that noradrenergic innervation from LC is needed to maintain adequate $\mathrm{A} \beta$ uptake and clearance by microglia and that LC neuron degeneration in $\mathrm{AD}$ not only impairs neuron-neuron transmission but also may contribute to dysregulation of the normal neuron-glial interaction, abnormal glial reaction, defective $\mathrm{A} \beta$ clearance, and, eventually, neurodegeneration. In addition, our findings indicate that the roles of $\beta_{2} \mathrm{AR}$ in regulating microglial functions may be used in developing new therapeutic strategies in the treatment of AD.

\section{References}

Aloisi F, Ambrosini E, Columba-Cabezas S, Magliozzi R, Serafini B (2001) Intracerebral regulation of immune responses. Ann Med 33:510-515.

Bard F, Cannon C, Barbour R, Burke RL, Games D, Grajeda H, Guido T, Hu K, Huang J, Johnson-Wood K, Khan K, Kholodenko D, Lee M, Lieberburg I, Motter R, Nguyen M, Soriano F, Vasquez N, Weiss K, Welch B, et al. (2000) Peripherally administered antibodies against amyloid betapeptide enter the central nervous system and reduce pathology in a mouse model of Alzheimer disease. Nat Med 6:916-919.

Blandino P Jr, Barnum CJ, Deak T (2006) The involvement of norepinephrine and microglia in hypothalamic and splenic IL-1beta responses to stress. J Neuroimmunol 173:87-95.

Bondareff W, Mountjoy CQ, Roth M, Rossor MN, Iversen LL, Reynolds GP, Hauser DL (1987) Neuronal degeneration in locus ceruleus and cortical correlates of Alzheimer disease. Alzheimer Dis Assoc Disord 1:256-262.

Carnevale D, De Simone R, Minghetti L (2007) Microglia-neuron interac- tion in inflammatory and degenerative diseases: role of cholinergic and noradrenergic systems. CNS Neurol Disord Drug Targets 6:388-397.

Chandrasekar B, Marelli-Berg FM, Tone M, Bysani S, Prabhu SD, Murray DR (2004) Beta-adrenergic stimulation induces interleukin-18 expression via beta2-AR, PI3K, Akt, IKK, and NF-kappaB. Biochem Biophys Res Commun 319:304-311.

Chen K, Iribarren P, Hu J, Chen J, Gong W, Cho EH, Lockett S, Dunlop NM, Wang JM (2006) Activation of Toll-like receptor 2 on microglia promotes cell uptake of Alzheimer disease-associated amyloid beta peptide. J Biol Chem 281:3651-3659.

Chen K, Iribarren P, Huang J, Zhang L, Gong W, Cho EH, Lockett S, Dunlop NM, Wang JM (2007) Induction of the formyl peptide receptor 2 in microglia by IFN-gamma and synergy with CD40 ligand. J Immunol 178:1759-1766.

Cook DG, Leverenz JB, McMillan PJ, Kulstad JJ, Ericksen S, Roth RA, Schellenberg GD, Jin LW, Kovacina KS, Craft S (2003) Reduced hippocampal insulin-degrading enzyme in late-onset Alzheimer's disease is associated with the apolipoprotein E-epsilon4 allele. Am J Pathol 162:313-319.

Cui YH, Le Y, Gong W, Proost P, Van Damme J, Murphy WJ, Wang JM (2002a) Bacterial lipopolysaccharide selectively up-regulates the function of the chemotactic peptide receptor formyl peptide receptor 2 in murine microglial cells. J Immunol 168:434-442.

Cui YH, Le Y, Zhang X, Gong W, Abe K, Sun R, Van Damme J, Proost P, Wang JM (2002b) Up-regulation of FPR2, a chemotactic receptor for amyloid beta 1-42 (A beta 42), in murine microglial cells by TNF alpha. Neurobiol Dis 10:366-377.

Dello Russo C, Boullerne AI, Gavrilyuk V, Feinstein DL (2004) Inhibition of microglial inflammatory responses by norepinephrine: effects on nitric oxide and interleukin-1beta production. J Neuroinflammation 1:9.

Eckman EA, Eckman CB (2005) Abeta-degrading enzymes: modulators of Alzheimer's disease pathogenesis and targets for therapeutic intervention. Biochem Soc Trans 33:1101-1105.

Färber K, Pannasch U, Kettenmann H (2005) Dopamine and noradrenaline control distinct functions in rodent microglial cells. Mol Cell Neurosci 29:128-138.

Farmer P, Pugin J (2000) beta-adrenergic agonists exert their "antiinflammatory" effects in monocytic cells through the IkappaB/NFkappaB pathway. Am J Physiol Lung Cell Mol Physiol 279:L675-682.

Frackowiak J, Wisniewski HM, Wegiel J, Merz GS, Iqbal K, Wang KC (1992) Ultrastructure of the microglia that phagocytose amyloid and the microglia that produce beta-amyloid fibrils. Acta Neuropathol 84:225-233.

Frautschy SA, Yang F, Irrizarry M, Hyman B, Saido TC, Hsiao K, Cole GM (1998) Microglial response to amyloid plaques in APPsw transgenic mice. Am J Pathol 152:307-317.

Freedman R, Foote SL, Bloom FE (1975) Histochemical characterization of a neocortical projection of the nucleus locus coeruleus in the squirrel monkey. J Comp Neurol 164:209-231.

Gong K, Li Z, Xu M, Du J, Lv Z, Zhang Y (2008) A novel protein kinase A-independent, beta-arrestin-1-dependent signaling pathway for $\mathrm{p} 38$ mitogen-activated protein kinase activation by beta2-adrenergic receptors. J Biol Chem 283:29028-29036.

González-Scarano F, Baltuch G (1999) Microglia as mediators of inflammatory and degenerative diseases. Annu Rev Neurosci 22:219-240.

Griffin WS, Sheng JG, Royston MC, Gentleman SM, McKenzie JE, Graham DI, Roberts GW, Mrak RE (1998) Glial-neuronal interactions in Alzheimer's disease: the potential role of a 'cytokine cycle' in disease progression. Brain Pathol 8:65-72.

Grudzien A, Shaw P, Weintraub S, Bigio E, Mash DC, Mesulam MM (2007) Locus coeruleus neurofibrillary degeneration in aging, mild cognitive impairment and early Alzheimer's disease. Neurobiol Aging 28:327-335.

Hardy JA, Higgins GA (1992) Alzheimer's disease: the amyloid cascade hypothesis. Science 256:184-185.

He R, Tan L, Browning DD, Wang JM, Ye RD (2000) The synthetic peptide Trp-Lys-Tyr-Met-Val-D-Met is a potent chemotactic agonist for mouse formyl peptide receptor. J Immunol 165:4598-4605.

Heneka MT, Galea E, Gavriluyk V, Dumitrescu-Ozimek L, Daeschner J, O’Banion MK, Weinberg G, Klockgether T, Feinstein DL (2002) Noradrenergic depletion potentiates beta-amyloid-induced cortical inflammation: implications for Alzheimer's disease. J Neurosci 22:2434-2442.

Heneka MT, Ramanathan M, Jacobs AH, Dumitrescu-Ozimek L, BilkeiGorzo A, Debeir T, Sastre M, Galldiks N, Zimmer A, Hoehn M, Heiss WD, Klockgether T, Staufenbiel M (2006) Locus ceruleus degeneration pro- 
motes Alzheimer pathogenesis in amyloid precursor protein 23 transgenic mice. J Neurosci 26:1343-1354.

Heneka MT, Nadrigny F, Regen T, Martinez-Hernandez A, DumitrescuOzimek L, Terwel D, Jardanhazi-Kurutz D, Walter J, Kirchhoff F, Hanisch UK, Kummer MP (2010) Locus ceruleus controls Alzheimer's disease pathology by modulating microglial functions through norepinephrine. Proc Natl Acad Sci U S A 107:6058-6063.

Hertz L, Lovatt D, Goldman SA, Nedergaard M (2010) Adrenoceptors in brain: Cellular gene expression and effects on astrocytic metabolism and $\left[\mathrm{Ca}^{2+}\right]$ i. Neurochem Int. Advance online publication. Retrieved July 13, 2010. doi:10.1016/j.neuint.2010.03.019.

Hickman SE, Allison EK, El Khoury J (2008) Microglial dysfunction and defective beta-amyloid clearance pathways in aging Alzheimer's disease mice. J Neurosci 28:8354-8360.

Hu JY, Le Y, Gong W, Dunlop NM, Gao JL, Murphy PM, Wang JM (2001) Synthetic peptide MMK-1 is a highly specific chemotactic agonist for leukocyte FPRL1. J Leukoc Biol 70:155-161.

Iribarren P, Chen K, Hu J, Gong W, Cho EH, Lockett S, Uranchimeg B, Wang JM (2005) CpG-containing oligodeoxynucleotide promotes microglial cell uptake of amyloid beta 1-42 peptide by up-regulating the expression of the G-protein-coupled receptor mFPR2. FASEB J 19:2032-2034.

Jiang Q, Lee CY, Mandrekar S, Wilkinson B, Cramer P, Zelcer N, Mann K, Lamb B, Willson TM, Collins JL, Richardson JC, Smith JD, Comery TA, Riddell D, Holtzman DM, Tontonoz P, Landreth GE (2008) ApoE promotes the proteolytic degradation of Abeta. Neuron 58:681-693.

Johnson JD, Campisi J, Sharkey CM, Kennedy SL, Nickerson M, Greenwood BN, Fleshner M (2005) Catecholamines mediate stress-induced increases in peripheral and central inflammatory cytokines. Neuroscience 135:1295-1307.

Kalinin S, Gavrilyuk V, Polak PE, Vasser R, Zhao J, Heneka MT, Feinstein DL (2007) Noradrenaline deficiency in brain increases beta-amyloid plaque burden in an animal model of Alzheimer's disease. Neurobiol Aging 28:1206-1214.

Kreutzberg GW (1996) Microglia: a sensor for pathological events in the CNS. Trends Neurosci 19:312-318.

Le Y, Gong W, Tiffany HL, Tumanov A, Nedospasov S, Shen W, Dunlop NM, Gao JL, Murphy PM, Oppenheim JJ, Wang JM (2001) Amyloid $\beta_{42}$ activates a G-protein-coupled chemoattractant receptor, FPR-like-1. J Neurosci 21: RC123.

Le Y, Murphy PM, Wang JM (2002) Formyl-peptide receptors revisited. Trends Immunol 23:541-548.

Leissring MA, Farris W, Chang AY, Walsh DM, Wu X, Sun X, Frosch MP, Selkoe DJ (2003) Enhanced proteolysis of beta-amyloid in APP transgenic mice prevents plaque formation, secondary pathology, and premature death. Neuron 40:1087-1093.

Liu AM, Lo RK, Wong CS, Morris C, Wise H, Wong YH (2006) Activation of STAT3 by G alpha(s) distinctively requires protein kinase A, JNK, and phosphatidylinositol 3-kinase. J Biol Chem 281:35812-35825.

Liu Y, Walter S, Stagi M, Cherny D, Letiembre M, Schulz-Schaeffer W, Heine H, Penke B, Neumann H, Fassbender K (2005) LPS receptor (CD14): a receptor for phagocytosis of Alzheimer's amyloid peptide. Brain 128:1778-1789.

Lombardo JA, Stern EA, McLellan ME, Kajdasz ST, Hickey GA, Bacskai BJ, Hyman BT (2003) Amyloid-beta antibody treatment leads to rapid normalization of plaque-induced neuritic alterations. J Neurosci 23:10879-10883.

Loughlin AJ, Woodroofe MN, Cuzner ML (1993) Modulation of interferongamma-induced major histocompatibility complex class II and Fc receptor expression on isolated microglia by transforming growth factor-beta 1 , interleukin-4, noradrenaline and glucocorticoids. Immunology 79:125-130.

Madrigal JL, Feinstein DL, Dello Russo C (2005) Norepinephrine protects cortical neurons against microglial-induced cell death. J Neurosci Res 81:390-396.

Marcyniuk B, Mann DM, Yates PO (1986) Loss of nerve cells from locus coeruleus in Alzheimer's disease is topographically arranged. Neurosci Lett 64:247-252.

Mori K, Ozaki E, Zhang B, Yang L, Yokoyama A, Takeda I, Maeda N, Sakanaka M, Tanaka J (2002) Effects of norepinephrine on rat cultured microglial cells that express alpha1, alpha2, beta1 and beta2 adrenergic receptors. Neuropharmacology 43:1026-1034.
Mudher A, Lovestone S (2002) Alzheimer's disease-do tauists and baptists finally shake hands? Trends Neurosci 25:22-26.

Nishida Y, Ito S, Ohtsuki S, Yamamoto N, Takahashi T, Iwata N, Jishage K, Yamada H, Sasaguri H, Yokota S, Piao W, Tomimitsu H, Saido TC, Yanagisawa K, Terasaki T, Mizusawa H, Yokota T (2009) Depletion of vitamin $\mathrm{E}$ increases amyloid beta accumulation by decreasing its clearances from brain and blood in a mouse model of Alzheimer disease. J Biol Chem 284:33400-33408.

Paresce DM, Ghosh RN, Maxfield FR (1996) Microglial cells internalize aggregates of the Alzheimer's disease amyloid beta-protein via a scavenger receptor. Neuron 17:553-565.

Pocock JM, Liddle AC, Hooper C, Taylor DL, Davenport CM, Morgan SC (2002) Activated microglia in Alzheimer's disease and stroke. Ernst Schering Res Found Workshop 39:105-132.

Pow DV, Perry VH, Morris JF, Gordon S (1989) Microglia in the neurohypophysis associate with and endocytose terminal portions of neurosecretory neurons. Neuroscience 33:567-578.

Qian L, Hu X, Zhang D, Snyder A, Wu HM, Li Y, Wilson B, Lu RB, Hong JS, Flood PM (2009) beta2 Adrenergic receptor activation induces microglial NADPH oxidase activation and dopaminergic neurotoxicity through an ERK-dependent/protein kinase A-independent pathway. Glia 57:16001609.

Qiu WQ, Walsh DM, Ye Z, Vekrellis K, Zhang J, Podlisny MB, Rosner MR, Safavi A, Hersh LB, Selkoe DJ (1998) Insulin-degrading enzyme regulates extracellular levels of amyloid beta-protein by degradation. J Biol Chem 273:32730-32738.

Schägger H (2006) Tricine-SDS-PAGE. Nat Protoc 1:16-22.

Schenk D, Barbour R, Dunn W, Gordon G, Grajeda H, Guido T, Hu K, Huang J, Johnson-Wood K, Khan K, Kholodenko D, Lee M, Liao Z, Lieberburg I, Motter R, Mutter L, Soriano F, Shopp G, Vasquez N, Vandevert C, et al. (1999) Immunization with amyloid-beta attenuates Alzheimer-diseaselike pathology in the PDAPP mouse. Nature 400:173-177.

Selkoe DJ (1999) Translating cell biology into therapeutic advances in Alzheimer's disease. Nature 399:A23-A31.

Shimizu E, Kawahara K, Kajizono M, Sawada M, Nakayama H (2008) IL-4induced selective clearance of oligomeric beta-amyloid peptide(1-42) by rat primary type 2 microglia. J Immunol 181:6503-6513.

Simard AR, Soulet D, Gowing G, Julien JP, Rivest S (2006) Bone marrowderived microglia play a critical role in restricting senile plaque formation in Alzheimer's disease. Neuron 49:489-502.

Tahara K, Kim HD, Jin JJ, Maxwell JA, Li L, Fukuchi K (2006) Role of toll-like receptor signalling in Abeta uptake and clearance. Brain 129:3006-3019.

Takemoto Y, Yoshiyama M, Takeuchi K, Omura T, Komatsu R, Izumi Y, Kim S, Yoshikawa J (1999) Increased JNK, AP-1 and NF-kappa B DNA binding activities in isoproterenol-induced cardiac remodeling. J Mol Cell Cardiol 31:2017-2030.

Tanaka KF, Kashima H, Suzuki H, Ono K, Sawada M (2002) Existence of functional beta 1 - and beta2-adrenergic receptors on microglia. J Neurosci Res 70:232-237.

Thomas WE (1992) Brain macrophages: evaluation of microglia and their functions. Brain Res Brain Res Rev 17:61-74.

Tiffany HL, Lavigne MC, Cui YH, Wang JM, Leto TL, Gao JL, Murphy PM (2001) Amyloid-beta induces chemotaxis and oxidant stress by acting at formyl peptide receptor 2, a G protein-coupled receptor expressed in phagocytes and brain. J Biol Chem 276:23645-23652.

Tiscornia G, Singer O, Verma IM (2006) Production and purification of lentiviral vectors. Nat Protoc 1:241-245.

Tomozawa Y, Yabuuchi K, Inoue T, Satoh M (1995) Participation of cAMP and cAMP-dependent protein kinase in beta-adrenoceptor-mediated interleukin-1 beta mRNA induction in cultured microglia. Neurosci Res 22:399-409.

Wang O, Cai K, Pang S, Wang T, Qi D, Zhu Q, Ni Z, Le Y (2008) Mechanisms of glucose-induced expression of pancreatic-derived factor in pancreatic beta-cells. Endocrinology 149:672-680.

Webster SD, Yang AJ, Margol L, Garzon-Rodriguez W, Glabe CG, Tenner AJ (2000) Complement component Clq modulates the phagocytosis of Abeta by microglia. Exp Neurol 161:127-138.

Weinshenker D (2008) Functional consequences of locus coeruleus degeneration in Alzheimer's disease. Curr Alzheimer Res 5:342-345.

Weldon DT, Rogers SD, Ghilardi JR, Finke MP, Cleary JP, O’Hare E, Esler WP, Maggio JE, Mantyh PW (1998) Fibrillar beta-amyloid induces mi- 
croglial phagocytosis, expression of inducible nitric oxide synthase, and loss of a select population of neurons in the rat CNS in vivo. J Neurosci 18:2161-2173.

Wilcock DM, DiCarlo G, Henderson D, Jackson J, Clarke K, Ugen KE, Gordon MN, Morgan D (2003) Intracranially administered antiAbeta antibodies reduce beta-amyloid deposition by mechanisms both independent of and associated with microglial activation. J Neurosci 23:3745-3751.

Xu J, Drew PD (2006) 9-Cis-retinoic acid suppresses inflammatory responses of microglia and astrocytes. J Neuroimmunol 171:135-144.

Yan SD, Chen X, Fu J, Chen M, Zhu H, Roher A, Slattery T, Zhao L, Nagashima M, Morser J, Migheli A, Nawroth P, Stern D, Schmidt AM (1996) RAGE and amyloid-beta peptide neurotoxicity in Alzheimer's disease. Nature 382:685-691.

Yazawa H, Yu ZX, Takeda, Le Y, Gong W, Ferrans VJ, Oppenheim JJ, Li CC, Wang JM (2001) Beta amyloid peptide (Abeta42) is internalized via the
G-protein-coupled receptor FPRL1 and forms fibrillar aggregates in macrophages. FASEB J 15:2454-2462.

Ye RD (2009) FPR2/ALX. UCSD-Nature Molecule Pages. doi:10.1038/mp. a001648.01.

Ye RD, Boulay F, Wang JM, Dahlgren C, Gerard C, Parmentier M, Serhan CN, Murphy PM (2009) International Union of Basic and Clinical Pharmacology. LXXIII. Nomenclature for the formyl peptide receptor (FPR) family. Pharmacol Rev 61:119-161.

Ying G, Iribarren P, Zhou Y, Gong W, Zhang N, Yu ZX, Le Y, Cui Y, Wang JM (2004) Humanin, a newly identified neuroprotective factor, uses the $G$ protein-coupled formylpeptide receptor-like-1 as a functional receptor. J Immunol 172:7078-7085.

Zhu J, Wang O, Ruan L, Hou X, Cui Y, Wang JM, Le Y (2009) The green tea polyphenol (-)-epigallocatechin-3-gallate inhibits leukocyte activation by bacterial formylpeptide through the receptor FPR. Int Immunopharmacol 9:1126-1130. 